\title{
The difficulty of being a geo politician and a world historian
}

\section{Editorial}

Both Geopolitics and World History, linked together in the field of International Relations, are social sciences particularly adapted to our present era of planetarian globalization. At the same time, they have been confronted with suspicion by scientists following the general trend of extreme specialization who tend to contest the possibility of covering such vast areas of knowledge and still staying inside the limits of scientific research.

Geopolitics came to the fore at the turn of the $20^{\text {th }}$ century with German geographer Friedrich Ratzel (1844-1904) who combined space and time, geography and history. During my studies at the Sorbonne, in Paris, we were obliged as students of History, to follow classes of Geography in order to understand the inevitable relation between time and space.

Ratzel, in 1897, published his work on political geography, titled Politische Geographie, introducing the concepts of Vital Space or "Lebensraum" and social Darwinism which were later adopted by Hitler's national-socialism and linking his political geography to World History in his three volume work titled The History of Mankind, published in English in 1896. In 1901, he specifically published an essay called Lebensraum, the starting point of Geopolitics.

Thus Geopolitics, from the start was linked to capitalist expansionism, expressing the growth of German industrialism after the 1870 Franco-Prussian war and the subsequent development of imperialism, in the search of markets, bringing Germany into competition with Great Britain.

In response to German imperialism, Great Britain in the name of Halford Mackinder (1861-1947) produced its own geopolitical theory. Mackinder, an English geographer, published a paper in 1904 to defend the imperialism of the British Empire as a World Sea Empire, under the title The Geographical Pivot of History, formulating his "Heartland Theory", opposing British sea power to the continental power of Germany and Russia in a famous sentence, produced in 1919, when he served as an anti-Bolshevik and British High Commissioner in Southern Russia supporting White Russians: "Who rules East Europe commands the Heartland [Russia-Soviet Union]; who rules the Heartland commands the World-Island [Europe-AsiaAfrica]; who rules the World-Island commands the world" through British sea power.

In a second response to British imperialism, Hitler's Germany based its continental expansionism in the lands of the Heartland, on the works of German geographer Karl Haushofer (1869-1946) who had as his student Rudolf Hess, Hitler's second in command.

The link between geopolitics and world history is manifest in the influence German world historian Oswald Spengler (1880-1936), author of The Decline of the West, published in 1918 and 1922, had on Haushofer. Spengler was also the inspirer of the greatest world historian of the 20th century, British Arnold J. Toynbee (1889-1975), author of the monumental 12-volume A Study of History, which was published between 1934 and 1961.

\author{
Volume I Issue I - 2017 \\ Dimitri Kitsikis \\ Department of History, University of Ottawa, Canada
}

Correspondence: Dimitri Kitsikis, Department of History,

University of Ottawa, Ottawa, Canada,

Email Dimitri.Kitsikis@uottawa.ca

Received: May 28, 2017 | Published: May 29, 2017

Hitler in 1936 invited Toynbee to Berlin and expressed his appreciation of the historian's work emphasizing that German expansionism for Lebensraum was limited to the Eastern Slavic lands and was not directed against England. Toynbee supported Hitler as sincere and endorsed his message towards the English people in a confidential memorandum the historian sent to the British government.

Hitler was imprisoned with Rudolf Hess after the Munich Beer Hall Putsch in 1923. Haushofer then, spent six hours visiting them in prison, bringing with him a copy of Friedrich Ratzel's Political Geography.

From 1945 to the fall of the communist camp in 1989, geopolitics was ousted from academic circles as a false science supporting expansionist imperialist aims, especially the aims of Nazism. Having myself studied geopolitics at the Sorbonne and having published my Sorbonne Ph.D. dissertation on Propaganda and Pressure Groups in International Politics (Presses Universitaires de France, 1963), I was prevented from teaching Geopolitics in France and Canada.

Nevertheless, in the 1960s I developed my geopolitical theory that I named "Intermediary Region" of Civilisation between West and East, which I taught at Istanbul's Bogazici University to my student Ahmet Davutoglu, the future minister of Foreign Affairs and prime minister of Turkey, who adopted it and applied it in his vision of the restauration of the Ottoman Empire, a vision pursued today by President Tayyip Erdogan.

Nevertheless, after the fall of the Communist camp in 1989, and the triumphant affirmation of American political scientist Francis Fukuyama's book, The End of History and the Last Man (1992), pretending that the struggle for world domination was definitely won by free market capitalism over communism and nationalsocialism which became the final form of human government, Western Universities as well as the media and popular science were overwhelmed with Geopolitics, or at least by people who took pride of calling themselves geo politicians.

World History however continued as a science to be looked upon with suspicion by many highly specialized historians who already in the time of Toynbee were criticizing his work as filled with broad generalizations, as they were unable to understand how it was possible for a professional historian to be at the same time a specialist and a generalist. 
The answer to the above question had been given in ancient Greece, from the time of its sages to the time of the Italian Renaissance, during which the scientists were supposed to know everything. Thus the Italian Renaissance man, Leonardo da Vinci, could be called the last Greek sage for his tremendous handling of all domains of knowledge from art to philosophy, to technology and all sciences. This is why it was not a coincidence if world historians like Toynbee were able to grasp the Universe by starting their History specialization in Greek History.

\section{Acknowledgements}

None.

\section{Conflict of interest}

The author declares no conflict of interest. 